\title{
FROM A MONOMODAL RECIPE TO A MULTIMODAL OFFER. A TEXTOLOGICAL AND MEDIOLINGUISTIC APPROACH
}

\begin{abstract}
Not so long ago recipes were included in 'obvious' text types functioning ,unproblematically in the sphere of everyday life" 3 , because their relatively uncomplicated structure did not cause any difficulties with recognition and qualification, or with the genological description of individual text copies. This is both reproductive and productive competence of recipients and producers of text genres. Recipes operate without any obstacles related to their recognition, in official and private communication ${ }^{4}$. However, contemporary multimedia and multimodal forms of the existence of recipes seem to undermine the thesis about their obviousness. Taking this into consideration, should these multimodal and increasingly multifunctional beings be considered as a variant of a text pattern, a multimodal field of text genres in the meaning of Adamzik ${ }^{5}$, or perhaps a hypertext in its common understanding? ${ }^{6}$ Or maybe other typological possibilities come into play? The article aims to discuss the above doubts from the point of view of textual linguistics and mediolinguistics, and to consider typological possibilities on the example taken from digital media. Pragmalinguistic analysis of the research body of the above-mentioned multimodal internet offer allows the thesis that in media communication we are constantly confronted with newer, more and more sophisticated forms and ways of communication, which, due to their increasing complexity, are becoming more and more of a challenge for linguists trying to categorize and define them. Therefore, according to the
\end{abstract}

\footnotetext{
${ }^{1}$ Anna Hanus, PhD, Department of Applied Linguistics, Faculty of Philology, University of Rzeszów, ul. Maj. W. Kopisto 2B, 35-315 Rzeszów, corresponding author; e-mail: anhanus@ @2.pl. Dr Anna Hanus, Katedra Lingwistyki Stosowanej, Wydział Filologiczny, Uniwersytet Rzeszowski, ul. mjr. W. Kopisto 2B, 35-315 Rzeszów, autor korespondencyjny; e-mail: anhanus@o2.pl.

${ }^{2}$ Dorota Kaczmarek, PhD, Institute of German Philology, Department of German Linguistics, University of Lodz, ul. Pomorska 171/173, 90-236 Łódź; e-mail: dorota.kaczmarek@uni.lodz.pl. Dr Dorota Kaczmarek, Instytut Filologii Germańskiej, Zakład Językoznawstwa Niemieckiego, Uniwersytet Łódzki, ul. Pomorska 171/173, 90-236 Łódź; e-mail: dorota.kaczmarek@uni.lodz.pl.

${ }^{3}$ Compare K. Brinker, Linguistische Textanalyse. Eine Einführung in Grundbegriffe und Methoden, Berlin 2005, p. 128; K. Brinker, H. Cölfen, S. Pappert, Linguistische Textanalyse. Eine Einführung in Grundbegriffe und Methoden, Berlin 2014, p. 133.

${ }^{4}$ Ch. Gansel, F. Jürgens, Textlinguistik und Textgrammatik, Stuttgart 2007, p. 54.

5 Compare K. Adamzik, Die Zukunft der Textsortenlinguistik. Textsortennetze, Textsortenfelder, Textsorten im Verbund [w:] Zur Kulturspezifik von Textsorten, ed. U. Fix, S. Habscheid, J. Klein, Tübingen 2001; K. Adamzik, Textlinguistik. Grundlagen, Kontroversen, Berlin, Boston 2016.

${ }^{6}$ Compare K. Brinker, H. Cölfen, S. Pappert, Linguistische Textanalyse. Eine Einführung in Grundbegriffe und Methoden, Berlin 2014, p. 135.
} 
postulates of Adamzik ${ }^{7}$, we are trying above all to describe and illuminate the analyzed phenomenon from various perspectives.

Keywords: recipe, text genre, genre transformation, hybridization, multimodal offer, media formats, media transformation.

\section{INTRODUCTION: INITIAL CONSIDERATIONS AND FORMULATION OF THE RESEARCH QUESTION}

The present paper is an attempt to answer the following questions: whether the shift from the manuscript, initially fixed in a written language, to the cooking idea organized in a multi-modal manner and disseminated by the Internet has already resulted in a change in the text type or a media-related transformation of the "cooking recipe" pattern ${ }^{8}$. It stands to reason that various text types change their initial form due to media-related adaptations, linking them with other types and resulting in hybrids and forms leading to the development of new/modified text types and patterns ${ }^{9}$. Also, when in the case of functional texts one still speaks of "strongly standardized text types"10, the producers of such common texts (like e.g. cooking recipes) still approach their patterns quite freely. Cooking recipes, like many other functional texts, have their more or less fixed place 11 in the "textual space", which implies among others that they are connected both for their producers and for their recipients with a particular (that is: fixed) communicative function and may be identified on its basis. They are produced for a particular purpose and received with a specific expectation (as an interested recipient, one reaches for cooking recipes normally only when one wishes to try out a given dish).

Against the background of the above reflections, the authors would like to explore, with respect to a multi-modally organized cooking portal which a particular cooking recipe has been posted on, what speaks for a change in the text type or pattern. And, if indeed such a change is concluded, how and whether the dominant communicative act of such a cooking

${ }^{7}$ Compare K. Adamzik, Die Zukunft der Textsortenlinguistik. Textsortennetze, Textsortenfelder, Textsorten im Verbund [in:] Zur Kulturspezifik von Textsorten...

${ }^{8}$ Compare e.g. A. Wolańska-Köller, Das E-Kochrezept - Gegenwart oder immer noch Zukunft? [in:] Osnabrücker Beiträge zur Sprachtheorie (OBST), Vol. 87, 2015, p. 1ff; H.-J. Bucher, T. Gloning, $\mathrm{K}$. Lehnen, Medienformate: Ausdifferenzierung und Konvergenz - zum Zusammenhang von Medienwandel und Formatwandel [in:] Neue Medien - neue Formate: Ausdifferenzierung und Konvergenz in der Medienkommunikation, ed. H.-J. Bucher, T. Gloning, K. Lehnen, Frankfurt, New York 2010.

9 Compare e.g. U. Fix., Tendenzen des Textsortenwandels - Thesen [in:] Musterwandel - Sortenwandel. Aktuelle Tendenzen der diachronen Text(sorten)linguistik, ed. S. Hauser, U. Kleinberger, K.S. Roth, Frankfurt a.M. 2014, p. 20-21.

${ }^{10}$ Compare K. Brinker, H. Cölfen, S. Pappert, Linguistische Textanalyse. Eine Einführung in Grundbegriffe und Methoden, Berlin 2014, p. 139.

${ }^{11}$ K. Adamzik, Texte im Kulturvergleich. Überlegungen zum Problemfeld in Zeiten von Globalisierung und gesellschaftlicher Parzellierung [in:] MedienTextKultur. Linguistische Beiträge zur kontrastiven Medienanalyse, ed. M. Luginbühl, S. Hauser, 2010, p. 21. 
recipe as the one BESCHREIBEN/DESCRIBING ${ }^{12}$ is performed ${ }^{13}$. In this context, how should the extension and multi-modal adaptation of this act typical for the text type be performed as a DEMONSTRATION OF INDIVIDUAL OPERATIONS/VORMACHEN DER EINZELNEN ARBEITSSCHRITTE with a text linguistic or media linguistic description? Furthermore, what roles do linguistic and audiovisual resources in such multi-modally organized cooking recipes have? Those resources are used on the one hand in order to modernize classical cooking recipes and increase they attractiveness (e.g. cooking recipes accompanying various cooking shows) and, on the other hand, to allow the recipients of such products to express their orientation. Finally, how should multi-modally organized cooking portals be conceived? Which textual or media linguistic parameters speak for and which against their specific classification?

Undoubtedly, cooking recipes are a daily self-evident matter: “[...] written as well as oral texts with their respective social function [...] belong to self-evident matters of our culture and are used to deal with living together and the daily routine"14 [emphasis added by the authors]. Meanwhile, the manner in which the daily routine is ordered using text

${ }^{12}$ Regarding the cooking recipe, one may speak of other acts such as the guiding function [A. Wolańska-Köller, Funktionaler Textaufbau und sprachliche Mittel in Kochrezepten des 19. und frühen 20. Jahrhunderts. Perspektiven Germanistischer Linguistik, Stuttgart 2010; G. Fritz, Dynamische Texttheorie. Gießener Elektronische Bibliothek, Gießen 2013, p. 464., http://geb.uni-giessen.de/geb/volltexte/2013/9243/ (access: 10.03.2017)] and secondary functions such as an informative or even a reminder function [T. Gloning, Textgebrauch und sprachliche Gestalt älterer Kochrezepte (1350-1800). Ergebnisse und Aufgaben [in:] Textsorten deutscher Prosa vom 12./13. bis 18. Jahrhundert und ihre Merkmale, ed. F. Simmler, Bern u. a. 2002, p. 524-525; G. Fritz, Dynamische Texttheorie. Gießener Elektronische Bibliothek, Gießen 2013, p. 464., http://geb.uni-giessen.de/geb/volltexte/2013/9243/ (access: 10.03.2017); A. Wolańska-Köller, Funktionaler Textaufbau und sprachliche Mittel in Kochrezepten des 19. und frühen 20. Jahrhunderts. Perspektiven Germanistischer Linguistik, Stuttgart 2010; A. Wolańska-Köller, Das E-Kochrezept - Gegenwart oder immer noch Zukunft? [in:] Osnabrücker Beiträge zur Sprachtheorie (OBST), Vol. 87, 2015, p. 14]. The latter consists in "reminding someone who can cook a given dish of the details" [G. Fritz, Dynamische Texttheorie. Gießener Elektronische Bibliothek, Gießen 2013, p. 464, emphasis in original].

13 On communicative acts compare e.g. M. Wojtak, Gatunki prasowe. Lublin 2004; H.-J. Bucher, T. Gloning, K., Lehnen, Medienformate: Ausdifferenzierung und Konvergenz - zum Zusammenhang von Medienwandel und Formatwandel [in:] Neue Medien - neue Formate: Ausdifferenzierung und Konvergenz in der Medienkommunikation, ed. H.-J. Bucher, T. Gloning, K. Lehnen, Frankfurt a. M., New York 2010; H.E.H. Lenk, Methodologische Probleme des Textsortenvergleichs am Beispiel des Kommentars [in] Tekst i dyskurs. text und diskurs 5/2012, ed. Z. Bilut-Homplewicz, W. Czachur, Rzeszów, Warszawa 2012; H.E.H. Lenk, Zur Intertextualität des Zeitungskommentars. Musterbezüge - Diskurseinbindung - Text(sorten)vernetzung [in:] Kommunikationsformen in der Fach- und Gemeinsprache, ed. D. Kaczmarek. et al., Łódź 2016; H.-H. Lüger, Kontinuität im Wandel? Journalistisches Kommentieren zwischen Tradition und Innovation [in:] Quo vadis, Kommunikation? Kommunikation - Sprache - Medien, ed. I.-N. Crețu, Frankfurt a. M. 2015; H.-H. Lüger, Entwicklung der Medienlinguistik [in:] Beiträge zur Fremdsprachenvermittlung 58, 2016.

${ }^{14}$ U. Fix, Text und Textlinguistik [in:] Textlinguistik. 15 Einführungen, ed. N. Janich, Tübingen, 2008, p. 88. 
types $^{15}$, is determined among others by the influence exerted by the technical and mediarelated transformation. As a result, cooking recipes that initially used to be drawn up predominantly as written, unimodal or bimodal texts accompanied by an image, e.g. in cookbooks, must be adjusted to the new requirements of the buyer market (e.g. cooking recipes posted on cooking portals).

In the light of the above, the present paper shall be focused on the following issues:

(1.) typological classifications which may be applied to a cooking recipe such as the one selected by the authors,

(2.) multimodal categories which may be used to describe the whole cooking portal,

(3.) complex thematic and functional relations which may be observed.

\section{INTERMODULAR STRUCTURE OF A COOKING PORTAL (EXAMPLE)}

In the present paper, a Polish cooking portal (compare www.mniammniam.com) was analyzed, which, as many other similar portals, has a modular design (compare Fig. 1). The portal in question encompasses five modules sharing a direct thematic connection, a module in which the user of the website may develop their activities on a forum, as well as accompanying modules featuring, among others, hyperlinks and tags. All the indicated modules are in an intermodular interplay with one another insofar as they refer to the overarching theme of the cooking website, i.e.: "preparation of chicken roulades stuffed with kale and mold cheese". The second shared communicative act which determines the intermodular interplay in question is an advertisement of a Polish manufacturer of deep-frozen products, company Hortex. Therefore, looking at this multimodal framework from the perspective of everyday knowledge and information on text types, one may recognize Modules 3 and 4 explicitly as a "cooking recipe", whereas Module 5 may be qualified as such only conditionally, as the cooking instructions presented there are not complete with respect to their contents and are not conveyed in a customary manner. In contrast, the remaining modules perform other functions thanks to which the whole cooking offer may be considered as related.

Hence, the identified intermodular interrelations include the following:

(1.) All the modules show both thematic as well as functional relations, demonstrating a certain logical sequence, even if this is not the first characteristic criterion for a multimodally organized website (compare Figure 2$)^{16}$.

(2.) Modules 1 and 2 are a sort of introduction to a cooking recipe as on the one hand the visualization of the cooking result as a finished dish stimulates the appetite of recipients, and on the other hand they commend the health-related advantages of the ingredients used (e.g. of kale), at the same time indirectly reinforcing the market position of company Hortex.

(3.) Modules 3 and 4 show a thematic and functional relationship of equivalence with each other as both present the cooking recipe, even though different semiotic resources are applied. Module 3 is a short video with subtitles, whereas Module 4 includes a classi-

${ }^{15}$ Compare U. Fix, Die EIN-Text-Diskursanalyse. Unter welchen Umständen kann ein einzelner Text Gegenstand einer diskurslinguistischen Untersuchung sein? [in:] Diskurs - interdisziplinär Zugänge, Gegenstände, Perspektiven, ed. H. Kämper, I.H. Warnke, Berlin, Boston 2015, p. 317-333.

16 On non-linearity, compare e.g. A. Storrer, Hypertextlinguistik [in:] Textlinguistik. 15 Einführungen... 
cal text expressed using written language, whereby "classical" shall mean here that the text exhibits a typical text type sequential structure, that is it starts with a list of ingredients followed by a preparation description.

(4.) Module 5 is a multimodally organized series of images presenting selected relevant steps to prepare the dish. Additionally, short commentaries are placed below the images which verbalize once again the effect of a given step visualized by the images. Still, content-wise the whole module is not sufficiently complete to derive from it full dish preparation instructions.

(5.) On top of that, individual modules from 1 to 5 are thematically and functionally related to one another in two respects (compare Figure 1). Firstly, as already indicated, they render into language and image a cooking recipe. Secondly, all of them are linked by a shared communicative act (i.e. ADVERTISING Hortex), which is proved both by the company logo located in the modules as well as their active links to the website of the Polish manufacturer.

(6.) Modul 6 as well as accompanying modules are located outside of the above-mentioned sequence as, for the most part, they perform a complementary function to the center of the network which is formed by the cooking recipe. Furthermore, a functional crosslinking can be observed between Modules 6 and 10 as both of them are about interactions with users (in the case of Modul 6 on the forum and in the case of Modul $10-$ FB) who either rate the cooking recipe, submit improvement suggestions or exchange cooking ideas with one another.

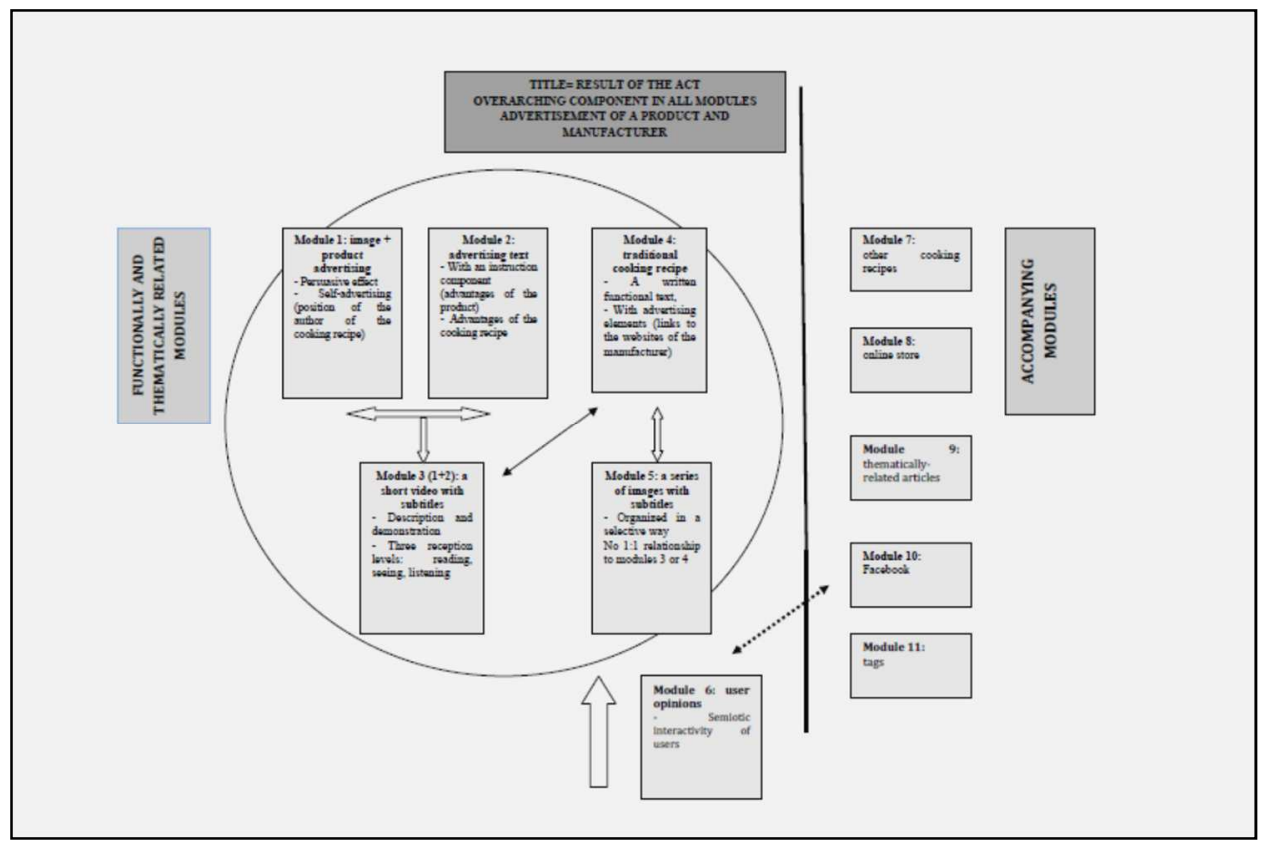

Figure 1. Thematic and functional interplay of modules

Source: compare http://www.mniammniam.com/Roladki_z_kurczaka_nadziewane_jarmuzem_i_serem_plesniowy podane_z_buraczkami_na_cieplo-21462p.html (access: 20.06.2017). 
The following screenshots show the structure of the website as well as the order of all the modules (compare Figure 2).

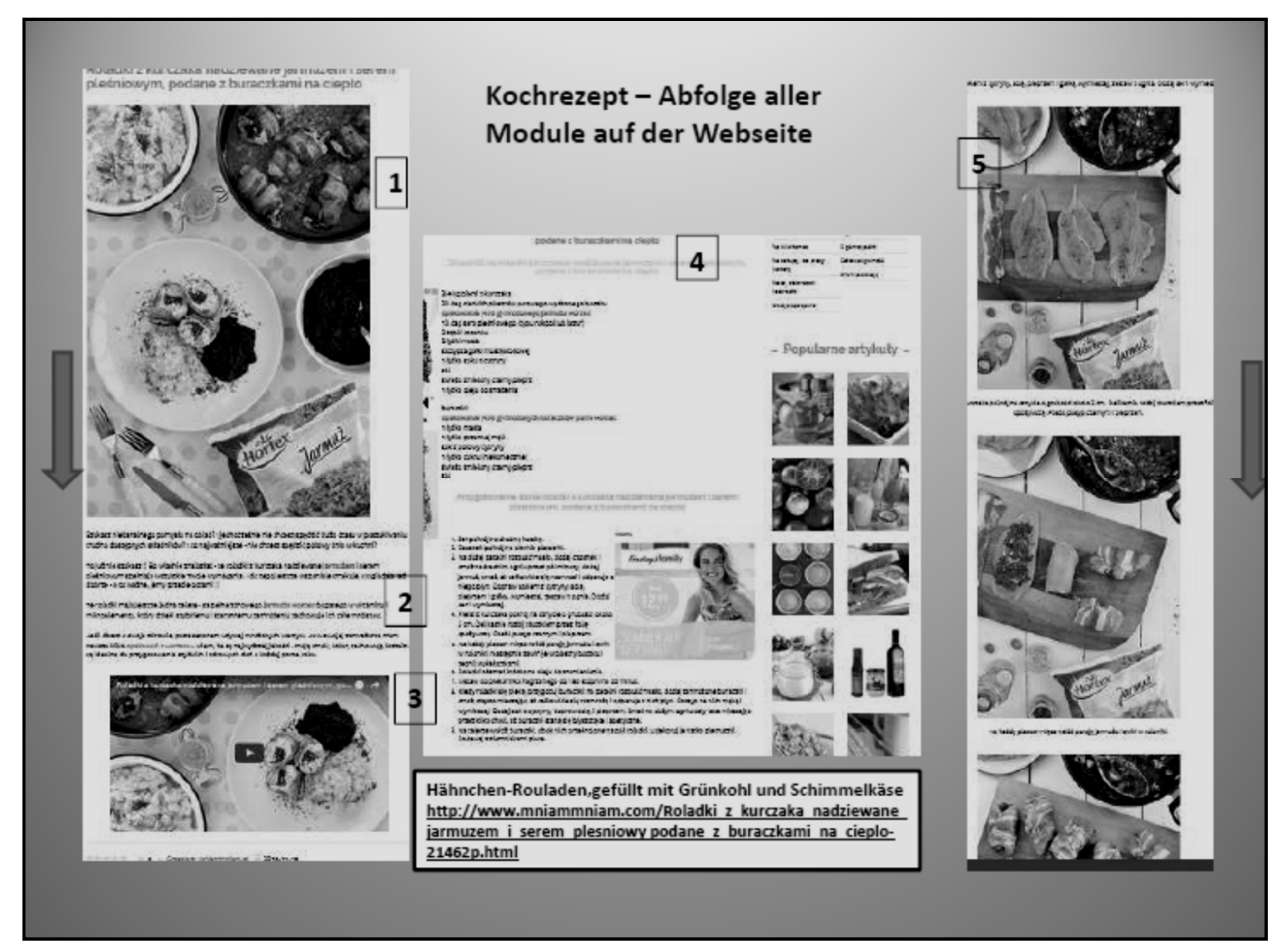

Figure 2. Sequence of the modules

Source: compare http://www.mniammniam.com/Roladki_z_kurczaka_nadziewane_jarmuzem_i_serem_plesniowy podane_z_buraczkami_na_cieplo-21462p.html (access: 20.06.2017)

The authors believe that the said multi-modal framework demonstrates a text-linguistic advantage that consists in the fact that the instruction specific for this text type which, after all, is functionally present in the presented cooking recipe, has a different multi-modal structure in each of them and is conveyed in a different way each time. This variability, as the authors claim, paves the way for different possibilities of typological classification of respective modules (compare chapter 3 ) and determination of the whole cooking portal in accordance with the categories of multimodality (compare chapter 4). Furthermore, the multimodal framework covering a cooking recipe should be perceived as a part of a larger aggregate (compare Chapter 5). The following sections are devoted to these aspects.

\section{TYPOLOGICAL RECOGNIZABILITY OF THE MODULES}

As already indicated, the whole multi-modal framework allows for various approaches to the "cooking recipe" as a text type. In some cases one can speak of a classical instance thereof (as in Module 4), whereas in others - of a multi-semiotic variation of this functional 
text type most commonly fixed in a written language (as in Module 3, i.e. a short video with subtitles).

Starting with a classical presentation of a cooking recipe as featured in Module 4, one may observe a media-related transformation of the text expressed in the form of a written language with a fixed structure into the so-called "natural text pattern style"17. As far as the pattern goes, the cooking recipe is delivered on the functional, text-structural and language-formulative level [on the levels of text description ${ }^{18}$ ] and is organized unimodally, except for the typographical emphasis of the links to the website of the manufacturer that are to be activated by the user. In the functional sense, an appellative and instructive text ${ }^{19}$ is produced with the dominant (invariable) communicative act BESCHREIBEN/DESCRIB$\mathrm{ING}^{20}$. Structurally, the text exhibits a sequential order customary for that text type (a list of ingredient and preparation steps) according to which also its typological classification and recognition as the 'cooking recipe' text type may be performed. Linguistically, its language dynamics and economy are manifested in the use of imperative sentences and participial attributes which are regarded as prototypical in the Polish instruction texts (such as pokrój na cienkie plastry, na dużej patelni rozgrzej masło ...; dodaj zamrożone buraczki...). Typologically, one can observe here a complete realization of the "cooking recipe" text type even though at the same time the medium used has been changed into an Internet presentation: the latter has not led to any significant pattern modifications.

In contrast, an analysis of Module 3 (a short video with subtitles) shows that despite being a step-by-step preparation description, it has been adjusted to the technical and mediarelated requirements of this form that have to do with the production of a cooking video on the one hand and related to posting the module on the website on the other. In this case, one can observe here a medium change and a transformation of the "cooking recipe" pattern resulting from $i^{21}$. Despite the fact that the typical communicative act typical of this text

17 B. Sandig, Textstilistik des Deutschen, Berlin, New York 2006.

18 Compare H.E.H. Lenk, Methodologische Probleme des Textsortenvergleichs am Beispiel des Kommentars [in:] Tekst i dyskurs. text und diskurs 5/2012..., p. 165.

${ }^{19}$ K. Brinker, H. Cölfen, S. Pappert, Linguistische Textanalyse. Eine Einführung in Grundbegriffe und Methoden. Berlin 2014, p. 111; K. Brinker, Linguistische Textanalyse. Eine Einführung in Grundbegriffe und Methoden, Berlin 2005, p. 117-125; G. Fritz, Dynamische Texttheorie. Gießener Elektronische Bibliothek, Gießen 2013, p. 464, http://geb.uni-giessen.de/geb/volltexte/2013/ 9243/ (access:10.03.2017).

${ }^{20}$ H. Cölfen, Vom Kochrezept zur Kochanaleitung. Sprachliche und mediale Aspekte einer verständlichen Vermittlung von Kochkenntnissen [in:] Essener Unikate 20, 2007; A. Wolańska-Köller, Funktionaler Textaufbau und sprachliche Mittel in Kochrezepten des 19. und frühen 20. Jahrhunderts. Perspektiven Germanistischer Linguistik, Stuttgart 2010; A. Wolańska-Köller, Das E-Kochrezept - Gegenwart oder immer noch Zukunft? [in] Osnabrücker Beiträge zur Sprachtheorie $(O B S T)$, Vol. 87, 2015.

${ }^{21}$ Compare H.-J. Bucher, T. Gloning, K. Lehnen, Medienformate: Ausdifferenzierung und Konvergenz - zum Zusammenhang von Medienwandel und Formatwandel [in:] Neue Medien - neue Formate..., p. 14; B. Witosz, Genologia Lingwistyczna. Zarys problematyki, Katowice 2005; B. Witosz, Grundlagen der Textsortenlinguistik, Frankfurt a. M. 2015; H. Stöckl, Medienlinguistik. Zu Status und Methodik eines (noch) emergenten Forschungsfeldes [in:] Pressetextsorten jenseits der ,News'. Medienlinguistische Perspektiven auf journalistische Kreativität, ed. Ch. Grösslinger et al., Frankfurt a. M. et al., 2012; U. Fix., Tendenzen des Textsortenwandels - Thesen [in:] Musterwandel-Sortenwandel. Aktuelle Tendenzen der diachronen Text(sorten)linguistik, ed. S. Hauser, U. Kleinberger, K.S. Roth, K. Frankfurt a. M. 2014. 
type BESCHREIBEN/DESCRIBING is preserved in the module, it is enriched through an additional one such as VORMACHEN DER EINZELNEN ARBEITSSCHRITTE/ DEMONSTRATION OF INDIVIDUAL OPERATIONS. This second communicative act results from the technical and medium-related adjustment of the cooking recipe to another medium format and is performed in Module 3 in the part where the cooking instruction is presented in the form of the film. Each sequence of the footage is additionally supported by subtitles which verbalize the events presented in the video and recounted by the chef. In this manner, several reception paths as well as various recipients are activated: the description of preparation steps expressed by subtitles may be read (which is relevant for persons with hearing impairments), one may also watch the demonstrated preparation steps, or one may listen to the utterances of the chef (which can be the case of the visually impaired). Therefore, in the opinion of the authors, Modul 3 may be deemed a multi-modal hybrid since it contains functional components of different communication forms and media formats (i.e. subtitles, which are a typical feature of films, elements of commercials, product placement and self-advertising), which together convey the cooking recipe in respective manners. As far as the linguistic structure is concerned, the material contains stylistic means which bring about intensification of the effect of a cooking recipe presented in such a form as compared to the cooking offer in 4 . Namely, repetitions have been applied such as to jest bardzo, bardzo smaczne, superlative forms: mrożonki Hortexu sa przepyszne as well as discursive means which create a sense of a community and are used by the chef when directly addressing recipients, e.g. to, co mnie $i$ was najbardziej interesuje... Such means are normally absent in classical cooking recipes. The whole design of Module 3 may be seen as a closed unit which, although it is perceived in a linear way, may be also absorbed selectively. For instance, one may switch over between the film sequences or stop the video and reset it. Putting the audiovisual material in the center of the module corresponds with the current expectations of recipients who prefer watching to reading. This phenomenon is rightly described by Skowronek as "wiek ekranów"/ 'the era of screens'22.

To sum up, the following has been concluded regarding Modules 3 and 4:

(1.) The cooking recipe organized in a multi-modal manner in Module 3 shall be understood as an instance of what consequences are brought about by the 'evolution' of the prototypical cooking recipe, i.e. a unimodal written text, which drives the media-related transformation of the pattern. In this regard, following ${ }^{23}$ one may speak of a certain intermedial principle of inertia, which in this case may imply that the original pattern of the classical cooking recipe including its function is mostly maintained but its transition into another medium and adopting another format (here: of a short video with subtitles) inevitably requires some modifications and adjustments.

(2.) As a result, although the dominant (invariant) communicative act BESCHREIBEN/ DESCRIBING is still performed, it is enriched by a further VORMACHEN DER EINZELNEN ARBEITSSCHRITTE/ DEMONSTRATION OF INDIVIDUAL OPERATIONS which usually is not delivered using a text fixed in a written language.

(3.) By contrast, the text inserted into Module 4 may be unequivocally classified as the 'cooking recipe' text type due to its linguistic, formal and functional characteristics. In this case, the change in the medium has not resulted in any particular modifications

\footnotetext{
22 B. Skowronek, Mediolingwistyka. Wprowadzenie, Kraków 2013, p. 29.

${ }^{23}$ Compare H.-J. Bucher, U. Püschel, Die Zeitung zwischen Print und Digitalisierung, Wiesbaden 2001.
} 
so that one may even claim that this is a cooking recipe fixed in a written language posted on the Internet. However, as compared to Module 4, such a cooking offer is fairly unappealing as regards its multi-modality. On the other hand, it is simple and can be quickly accessed.

(4.) Another difference is related to the reception direction. While Module 4 is basically "read" in a linear manner, it is not necessarily the case for the one in Module 3. An interested recipient may get familiar with it in a selective way and, as mentioned, may opt only for a particular reception path, e.g. by choosing only certain film sequences so as to get an overview of the whole cooking recipe.

\section{MULTIMODALITY OF THE COOKING OFFER: POTENTIAL WAYS TO DETERMINE IT}

Chapter 3 involved an attempt to address potential pattern (variants) of the cooking offer presented in respective modules to be analyzed. Now, the following question will be pursued against the background of the whole cooking offer: whether the comprehensive network in question may be defined or precisely described from a (media-)linguistic perspective.

The attempt to be undertaken will involve contrasting the structure to be analyzed with the already discussed media-linguistic forms. The purpose of this attempt will be to explore which multimodal categories might be used for the description of the structure. Moreover, the authors will try to investigate if the indicated modular cooking offer shares any characteristics of one or more text types and multimodal formats and whether in the present case one can speak of an adjustment to a new medium - which would imply a text type variant - a hybrid, or differentiation of a new format. Furthermore, the authors will address the question whether the structure exhibits at least some characteristics which might point to such processes or tendencies.

As already suggested, the whole cooking offer is composed of the so-called center of the network (Modules 1-5), which essentially fulfils two functions differentiated by Heinemann and Viehweger. These functions are steering and describing ${ }^{24}$. Moreover, the offer includes accompanying Modules 7-11 placed outside of the sequence (other cooking recipes, online stores, thematically related articles, FB, tags). Furthermore, user opinions have been isolated separately as Module 6 (compare Figure 3).

In the opinion of the authors, the described unit has been contrasted with two relevant (media)linguistic units. In this context, it was interesting to observe, from the perspective of the medium, that the analyzed cooking offer seemed to have been juxtaposed with a hypertext structure. However, given that hypertexts are defined in a different and partly divergent way, it should be mentioned that the hypertext in this article is understood in accordance with Storrer's definition ${ }^{25}$ and demonstrates characteristics of a hypertext compiled and described by Flender and Christmann in the year $2000^{26}$.

${ }^{24}$ Compare W. Heinemann, D. Viehweger, Textlinguistik. Eine Einführung, Tübingen 1991.

${ }^{25}$ Compare A. Storrer, Hypertextlinguistik [in:] Textlinguistik. 15 Einführungen...

${ }^{26}$ Flender, Christmann distinguishes two fundamental and several complementary characteristics. The fundamental ones refer to computer administration and non-linearity. The other features considered which is characteristic of hypertexts and may be observed are: multimodal codification, dynamics (texts may be always subject to modifications and updates), interactivity and computer- 


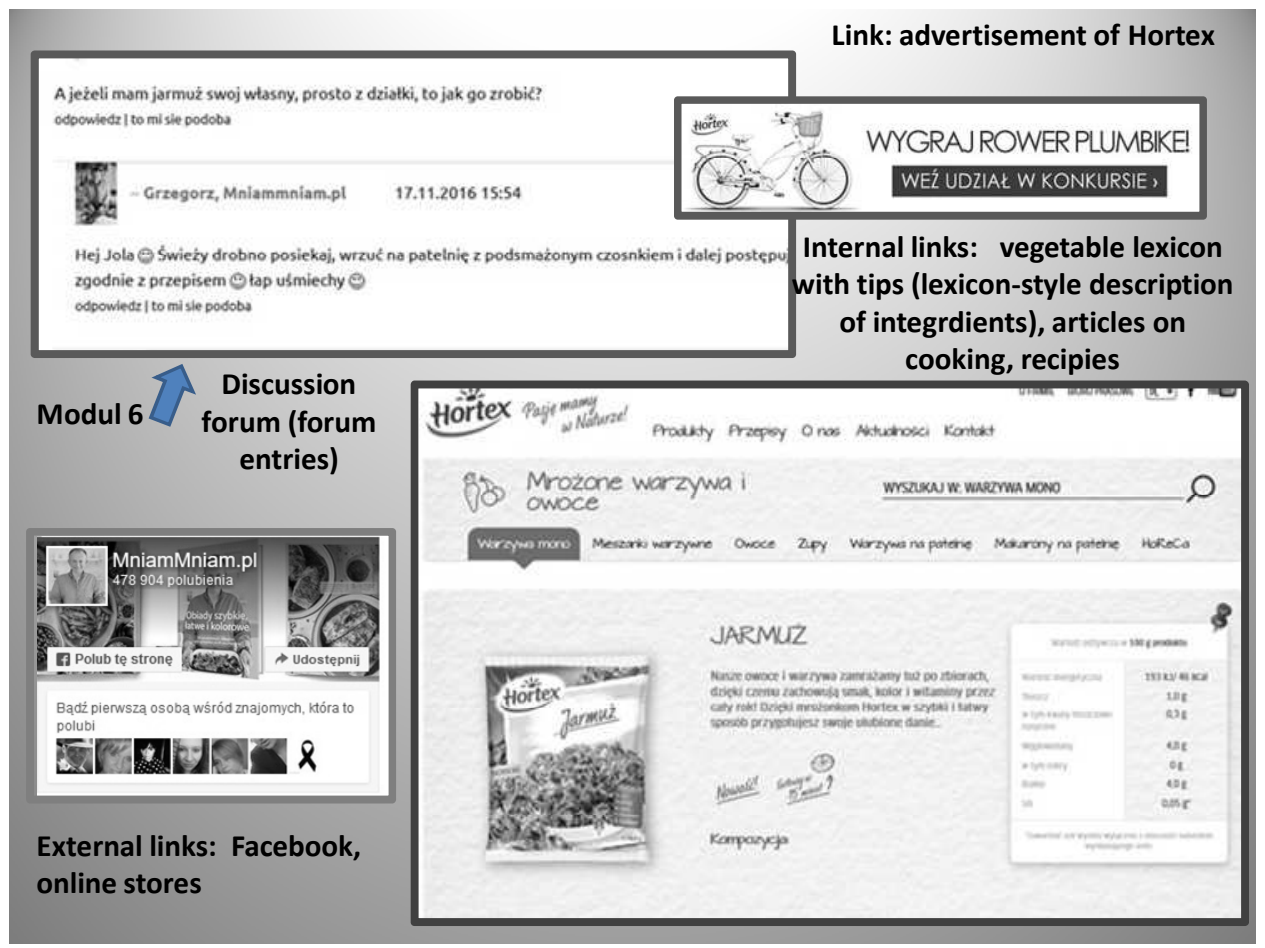

Figure 3. Accompanying modules 7-11 and the modul 6

Source: compare http://www.mniammniam.com/Roladki_z_kurczaka_nadziewane_jarmuzem_i_serem_plesniowy podane_z_buraczkami_na_cieplo-21462p.html (access:20.06.2017).

Without doubt, an observable feature of the explored entity which is specific for hypertexts is its non-linear, modular form whose individual components are not bound by the cause and effect relations and may be received in a random order. Another element that speaks in favor of a hypertextual order is the fact that individual modules of the cooking offer are connected by the means of links that help and encourage to additionally dive into the hypertextual structure. Also, individual components may be verified, shared, supplemented or certain information may be updated or deleted since the person in charge of the website may make changes and updates at any time. Another decisive feature that may be considered specific for a hypertext is the interactivity of the analyzed entity. It is interactive both in the sense of interactions between persons and the computer system, when the software reacts on the inputs of users in a preprogrammed manner ${ }^{27}$, as well as between individual computer users (computer-mediated communication $)^{28}$. Another, and still a key,

mediated communication. Compare J. Flender, U. Christmann, Hypertext: prototypische Merkmale und deren Realisierung im Hypertext "Visuelle Wahrnehmung" [in:] Medienpsychologie 12, 2000.

27 J. Haack, Interaktivität als Kennzeichen von Multimedia und Hypermedia [in:] Information und Lernen mit Multimedia, ed. L. J. Issing, P. Klimsa, Weinheim, 1995.

28 A. Storrer, Hypertextlinguistik [in:] Textlinguistik. 15 Einführungen... 
feature of the analyzed cooking offer which should be mentioned is the fact that in the presented case just like in the case of hypertexts, various transmission forms are observable. Some examples include texts, images, photos, tables, graphics, videos, sound recordings etc. However, crucial disputed cases result from the fact that hypertexts per definitionem have no clear beginning and no clear ending. It is also questionable whether a multimodal offer that leads from a cooking recipe as a film, a cooking instruction as an image series with subtitles, a cooking recipe in a classical form with the list of ingredients and description of preparation, an advertisement of Hortex, an advertisement of the presented cooking recipe, a discussion forum on the published recipes as well as numerous hyperlinks that send to the addresses of food and household appliance online stores as well as wine advisors may be still classified as the "cooking recipe" text type.

From the perspective of the attempts to allocate them, one should mention the concept of a text cluster developed by Ulrich Püschel ${ }^{29}$. If one compares the basic principles of a text cluster order with the entity analyzed in the present paper, one may detect several similarities. Just like in the case of the text cluster principle, also in the analyzed material one is confronted with a non-linear, modular form of organization similar to a collage consisting of an ensemble of numerous short, palatable information or opinion marked texts. Also here, like in the case of text clusters, individual modules are not bound by cause and effect relations. Thus, the recipient is free to decide on the selection or sequence of cluster parts which he/she is taking note of ${ }^{30}$. Hence, not all the modules need to be taken into account by the reader. Yet, essentially for the described materials, the materials share the same theme, i.e. in this case a cooking offer. Therefore, such manifestations are relatively complete. Another important characteristics that speaks in favor of classifying our cooking offer as a cluster within the meaning proposed by Püschel is the abundance of images, graphics, tables, infographics, photos or image series bearing a shared title, as well as lexicon and dictionary entries in the form of mini-dictionaries and minilexicons ${ }^{31}$. However, what is inconsistent with the notion of text clusters introduced by Püscheler, or at least seems questionable, is the fact that our cooking offer, in contrast with clusters in their prototypical form is not bound to printed media. Unlike with text clusters which following their publication are not subject to changes or their components may not be exchanged, in the case of computer-administered forms one has the option - and it applies to the analyzed material - to introduce changes, updates and supplements.

Summing up the conclusions presented so far, one should note that the analyzed multimedial entity exhibits numerous features that point both to a hypertextual structure and are characteristic of the cluster principle. However, for the presented text cluster order it should be mentioned that in this case one may speak rather of a media change and the related adjustment of the cluster principle to the technical and media-related requirements of the

\footnotetext{
${ }^{29}$ Compare U. Püschel, Von der Pyramide zum Cluster. Textsorten und Textsortenmischung in Fernsehnachrichten [in:] Medienkultur - Kulturkonflikt. Massenmedien in der interkulturellen und internationalen Kommunikation, ed. E.W.B. Hess-Lüttich, Opladen 1992; U. Püschel, „PuzzleTexte“ - Bemerkungen zum Textbegriff [in:] Die Zukunft der Textlinguistik. Traditionen, Transformationen, Trends, ed. G. Antos, H. Tietz, Tübingen 1997, p. 38.

${ }^{30}$ Compare e.g. J. Blum, H.-J. Bucher, Die Zeitung: Ein Multimedium. Textdesign - ein Gestaltungskonzept für Text, Bild und Grafik. Konstanz 1998.

${ }^{31}$ Compare U. Püschel, ,Puzzle-Texte“-Bemerkungen zum Textbegriff [in:] Die Zukunft der Textlinguistik. Traditionen..., p. 38.
} 
media format (audio material, film sequences with subtitles). Consequently, it is worthwhile indicating that the semiotic complexity of the analyzed cooking offer results in all likelihood from the interplay of several verbal and visual components and codes, which is specific for modern media.

The issue of development and significance of the "cooking recipe" text type within the media and technical context seems to be much more difficult to answer. An attempt to do that will be undertaken in the following part of the paper.

\section{LOCATION OF THE COOKING OFFER WITHIN MORE COMPLEX RELATIONS}

The multimodal network selected for the present analysis as well as its individual modules are obviously not isolated but rather result either from larger complexes or are incorporated into such complexes ${ }^{32}$. The basis for these reflections are insights from text and media linguistics implying that anything which is produced in media as a result of communicative acts is linked to one another by thematic or functional links ${ }^{33}$. In this context, the following forms of links shall be discussed:

(1.) The selected cooking website may be integrated into the whole "program" of the chef ${ }^{34}$ which is characterized by spatial linearity and serial occurrence of the modules. This means that respective modules of the cooking website form parts of the "program", whereas the "program" itself is to be understood as all multimodal cooking ideas of the same author on his/her website. Hence, it pertains to the network of various modules in terms of their theme, which however are similar as regards their functionality as each cooking idea has a different topic (it offers a different cooking recipe) but the functional arrangement of the modules - irrespective of the topic - is more or less the same. For instance Modul 3, which contains a classical pattern, seems almost always to have the same place, the cooking video (Modul 4) has a different place, whereas Modul 5 (photo series) has been also assigned with its fixed place. In this manner individual modules exist serially, which essentially facilitates the website navigation in the course of the reception process. A regular user of the website becomes accustomed with its structure and will quickly locate the modules he/she is interested in.

${ }^{32}$ What is meant here are text (type) networks or discourses characterized by various degrees of complexity compare K. Adamzik, Textsortennetze [in:] Textsorten, Handlungsmuster, Oberflächen. Linguistische Typologien der Kommunikation, ed. S. Habscheid, Berlin, Boston 2011, W. Holly, Medien, Kommunikationsformen, Textsortenfamilien [in:] Textsorten, Handlungsmuster, Oberflächen...

${ }^{33}$ Compare K. Adamzik, Texte im Kulturvergleich. Überlegungen zum Problemfeld in Zeiten von Globalisierung und gesellschaftlicher Parzellierung [in:] MedienTextKultur. Linguistische Beiträge zur kontrastiven Medienanalyse, ed. M. Luginbühl, S. Hauser, 2010; W. Holly, Medien, Kommunikationsformen, Textsortenfamilien [in:] Textsorten, Handlungsmuster, Oberflächen...; H. Stöckl, Medienlinguistik. Zu Status und Methodik eines (noch) emergenten Forschungsfeldes [in:] Pressetextsorten jenseits der, News'. Medienlinguistische Perspektiven auf journalistische Kreativität, ed. Ch. Grösslinger et al., Frankfurt a. M. et al., 2012.

${ }^{34}$ On the "program" compare K. Adamzik, Texte im Kulturvergleich. Überlegungen zum Problemfeld in Zeiten von Globalisierung und gesellschaftlicher Parzellierung [in:] MedienTextKultur. Linguistische Beiträge..., p. 31. 
(2.) Modules as parts of the text (type) family characterized by spatial separation, which perform the same communicative act and occur in various communication forms. In this case, the concept applied is the one of a text type family ${ }^{35}$ or a text type field ${ }^{36}$. Despite different approaches behind those two concepts (Holly is an advocate of Wittgenstein's concept of language games, whereas Adamzik is preoccupied with word families), in the case of both texts, text (type) relations fulfill the same or a similar function when delivering various communication forms and play an essential role using different resources. Analogically, it is quite conceivable that the cooking recipe shown in Modules 3 and 4 could be presented by the chef using different communication forms such as an advertising brochure. Alternatively, Hortex could just as well put it on the packaging of their products (deep-frozen kale). The cooking recipe could furthermore be used as a contestant in a cooking show or, as a tried-and-tested recipe, be shared by users via text messages in the form of the so-called word-ofmouth advertising. Upon each change in the medium or a transition into another communication form, it will be adjusted to its respective requirements and possibly abridged.

\section{SUMMARY}

A pragmatic and corpus-based analysis of the presented material, conducted using a bottom-up procedure, has shown that different approaches to the examined entity may arise, depending on the research perspective and the defined research field.

When one considers primarily the main modules linked functionally and thematically with one another, simultaneously diminishing the role of accompanying Modules 7-11, one may observe a medium change determined transformation of the "cooking recipe" pattern resulting from technical and media-related adaptation of the cooking recipe to a respective medium format. Whereby the dominant appellative and instructive function, i.e. to encourage to cook, has been preserved. The pattern and contents of a cooking recipe even when a text type has been adjusted to a new medium have been maintained. Even the complementarity of the applied code may be ultimately interpreted as a way of adjusting to a modern, electronically mediated form of communication. Moreover the fact that all the functional components are placed on a single internet site seems to be of significance.

However, what causes certain doubts as to the description of the said text type and its place within electronically mediated communication are numerous advertising elements, such as product placement, promotion of Hortex as well as self-advertising of the author of the cooking portal who presents his cooking performances. The appellative and instructive function of the cooking recipe is accompanied by another one, which is the persuasive function. In the opinion of the authors of this paper, the introduction of advertising elements as

35 On this topic within Polish philology compare Witosz [B. Witosz, Grundlagen der Textsortenlinguistik, Frankfurt a. M. 2015, p. 164-165]. Accordingly, two text relations have been distinguished, that is the one of "neighborhood"/ "sąsiedztwo" with an intermedial change and 'kinship'/ "pokrewieństwo" with a joint thematic and functional component that determines the related texts. Compare W. Holly, Medien, Kommunikationsformen, Textsortenfamilien [in:] Textsorten, Handlungsmuster, Oberflächen..., p. 157.

${ }^{36}$ K. Adamzik, Textsortennetze [in:] Textsorten, Handlungsmuster, Oberflächen..., p. 37; K. Adamzik, Textlinguistik Grundlagen, Kontroversen, Berlin, Boston, 2016, p. 339. 
well as of the additional function to the analyzed entity creates no danger for the existence and the position of the 'cooking recipe' text type.

Looking at the cooking recipe from the angle of the whole media offer, questions arise concerning its location and format specification. Can one observe a media transformation in the present case or rather is it a new media format? For the analyzed entity, patterns from the printed media, radio, and television have been further passed into a new medium or possibly combined with one another ${ }^{37}$. From the formal perspective, merely further modes are added, i.e. spoken language, images, moving images, sound and music. Still, what speaks in favor of a new media format are numerous solutions characteristic of the Internet such as the use of hyperlinks which lead the reader to the websites of online stores where he/she may purchase proper ingredients, devices, dishes as well as matching wines. There are also other not so commonly applied but still present solutions (calculation of required quantities of ingredients to prepare any number of portions or preparation of shopping lists with precise information on the quantities) that point to a gradual emancipation tendency of the format. What is considered to be a typical element of Internet communication is opinion exchange on forums as well as user opinions and comments - this form of communication is also present in the case of the analyzed module network, where users are provided access to it in order to exchange freely on the presented cooking offer, as well as submit their own impressions on the taste of the dish, modification suggestions and their own recipes. However, such forms are used frequently for the purposes of particular persons, e.g. to agitate, advertise or self-advertise. It is also for advertising purposes that many expressions of the portal owner are produced that is the person publishes advertising slogans in his cooking recipes and film sequences on the preparation of dishes as well as links to internet sites of particular online stores. In this context there is risk that the persuasive function may gradually dominate over the one of steering and describing.

Having enumerated all pros and cons with respect to the media transformation or a new media format, the position of the authors is that in the present case one may observe transformation of the 'cooking recipe' text type into a complex multi-modal communication offer whose communicative goal as well as the main function is maintained, but it has undergone an adjustment to the modern media reality and the needs of modern users including all the available shopping offers and possibilities, discussion opportunities, consulting offers and tipps on healthy products, as well as a lexicon of food products.

A question which remains unanswered is the on how such complex units, "multimodal or multi-code complete products", using the notion of Lüger, should be named $^{38}$ [emphasis in the original version]. Since the linear unimodal written form of semiotic complexity, demonstrating and disseminating an interplay of verbal, acoustic and visual is growingly common, one speaks of texts increasingly rarely. The modern media linguistics makes an increasing use of the term "Kommunikat'/"message". For such messages as the one described in the present paper, we propose, following Bucher, that the term "multi-

${ }^{37}$ Compare H.-J. Bucher, Gedrucktes im Internet. Online-Zeitungen und Online-Magazine auf dem Weg zu einer eigenständigen Mediengattung [in:] Von *hdl* bis *cul8r*. Sprache und Kommunikation in den neuen Medien, ed. P. Schlobinski, Mannheim 2006.

${ }^{38}$ Compare H.-H. Lüger, Entwicklung der Medienlinguistik [in:] Beiträge zur Fremdsprachenvermittlung 58, 2016, p. 64. 
modal communication offer" be used. This is because this notion ${ }^{39}$ resorts to the possibilities provided to the recipients concerning the use of various modes in a communication offer ("individual elements may be placed by the recipients in various relations [...] ${ }^{640}$ ) and hence the process of reception may be steered. After all, as a result of the non-linearity and discontinuity of multimodal communication offers it is the recipients that are to make an overall sense of multimodal offers, hence causing its relativization.

\section{REFERENCES}

1. Adamzik K., Die Zukunft der Textsortenlinguistik. Textsortennetze, Textsortenfelder, Textsorten im Verbund [in:] Zur Kulturspezifik von Textsorten, ed. U. Fix, S. Habscheid, J. Klein, Tübingen 2001.

2. Adamzik K., Textlinguistik: Eine einführende Darstellung, Tübingen 2004.

3. Adamzik K., Texte im Kulturvergleich. Überlegungen zum Problemfeld in Zeiten von Globalisierung und gesellschaftlicher Parzellierung [in:] MedienTextKultur. Linguistische Beiträge zur kontrastiven Medienanalyse, ed. M. Luginbühl, S. Hauser, Landau 2010.

4. Adamzik K., Textsortennetze [in:] Textsorten, Handlungsmuster, Oberflächen. Linguistische Typologien der Kommunikation, ed. S. Habscheid, Berlin, Boston 2011.

5. Adamzik K., Textlinguistik. Grundlagen, Kontroversen. Berlin, Boston 2016.

6. Brinker K., Linguistische Textanalyse. Eine Einführung in Grundbegriffe und Methoden, Berlin 1987.

7. Brinker K., Linguistische Textanalyse. Eine Einführung in Grundbegriffe und Methoden, Berlin 2005.

8. Brinker K., Cölfen H., Pappert S., Linguistische Textanalyse. Eine Einführung in Grundbegriffe und Methoden, Berlin 2014.

9. Blum J., Bucher H.-J., Die Zeitung: Ein Multimedium. Textdesign-ein Gestaltungskonzept für Text, Bild und Grafik, Konstanz 1998.

10. Bucher H.-J., Gedrucktes im Internet. Online-Zeitungen und Online-Magazine auf dem Weg zu einer eigenständigen Mediengattung [in:] Von *hdl* bis *cul8r*. Sprache und Koтmunikation in den neuen Medien, ed. P. Schlobinski, Mannheim 2006.

11. Bucher H.-J., Multimodalität - eine Universalie des Medienwandels: Problemstellungen und Theorien der Multimodalitätsforschung [in:] Neue Medien - neue Formate: Ausdifferenzierung und Konvergenz in der Medienkommunikation, ed. H.-J. Bucher, T. Gloning, K. Lehnen, Frankfurt a. M., New York 2010.

12. Bucher H.-J., Multimodales Verstehen oder Rezeption als Interaktion. Theoretische und empirische Grundlagen einer systematischen Analyse der Multimodalität [in:] Bildlinguistik. Theorien - Methoden - Fallbeispiele, ed. H. Dieckmannshenke, M. Klemm, H. Stöckl, Berlin 2011.

13. Bucher H.-J., Püschel U., Die Zeitung zwischen Print und Digitalisierung, Wiesbaden 2001.

\footnotetext{
${ }^{39}$ Compare H.-J. Bucher, Multimodales Verstehen oder Rezeption als Interaktion. Theoretische und empirische Grundlagen einer systematischen Analyse der Multimodalität [in:] Bildlinguistik. Theorien - Methoden - Fallbeispiele, ed. H. Dieckmannshenke, M. Klemm, H. Stöckl, Berlin 2011.

${ }^{40}$ Ibidem, p. 138.
} 
14. Bucher H.-J., Gloning T., Lehnen K., Medienformate: Ausdifferenzierung und Konvergenz - zum Zusammenhang von Medienwandel und Formatwandel [in:] Neue Medien - neue Formate: Ausdifferenzierung und Konvergenz in der Medienkommunikation, ed. H.-J. Bucher, T. Gloning, K. Lehnen, Frankfurt a. M., New York 2010.

15. Cölfen H., Vom Kochrezept zur Kochanaleitung. Sprachliche und mediale Aspekte einer verständlichen Vermittlung von Kochkenntnissen [in:] Essener Unikate 20, Essen 2007.

16. Fix U., Text und Textlinguistik [in:] Textlinguistik. 15 Einführungen, ed. N. Janich, Tübingen, 2008.

17. Fix U., Tendenzen des Textsortenwandels - Thesen [in:] Musterwandel - Sortenwandel. Aktuelle Tendenzen der diachronen Text(sorten)linguistik, ed. S. Hauser, U. Kleinberger, K.S. Roth, Frankfurt a. M. 2014.

18. Fix U., Die EIN-Text-Diskursanalyse. Unter welchen Umständen kann ein einzelner Text Gegenstand einer diskurslinguistischen Untersuchung sein? [in:] Diskurs - interdisziplinär Zugänge, Gegenstände, Perspektiven, ed. H. Kämper, I.H. Warnke, Berlin, Boston 2015.

19. Flender J., Christmann U., Hypertext: prototypische Merkmale und deren Realisierung im Hypertext "Visuelle Wahrnehmung" [w:] Medienpsychologie 12, 2000.

20. Gansel Ch., Jürgens F., Textlinguistik und Textgrammatik, Stuttgart 2007.

21. Gloning T., Textgebrauch und sprachliche Gestalt älterer Kochrezepte (1350-1800). Ergebnisse und Aufgaben [in:] Textsorten deutscher Prosa vom 12./13. bis 18. Jahrhundert und ihre Merkmale, ed. F. Simmler, Bern u. a. 2002.

22. Haack J., Interaktivität als Kennzeichen von Multimedia und Hypermedia [in:] Information und Lernen mit Multimedia, ed. L.J. Issing, P. Klimsa, Weinheim 1995.

23. Heinemann W., Viehweger D., Textlinguistik. Eine Einführung, Tübingen 1991.

24. Holly W., Medien, Kommunikationsformen, Textsortenfamilien [in:] Textsorten, Handlungsmuster, Oberflächen. Linguistische Typologien der Kommunikation, ed. S. Habscheid, Berlin, New York 2011.

25. Lenk H.E.H., Methodologische Probleme des Textsortenvergleichs am Beispiel des Kommentars [in:] Tekst i dyskurs. text und diskurs 5/2012, ed. Z. Bilut-Homplewicz, W. Czachur, Rzeszów, Warszawa 2012.

26. Lenk H.E.H., Zur Intertextualität des Zeitungskommentars. Musterbezüge - Diskurseinbindung - Text(sorten) vernetzung [in:] Kommunikationsformen in der Fach- und Gemeinsprache, ed. D. Kaczmarek et al., Łódź 2016.

27. Lüger H.-H., Kontinuität im Wandel? Journalistisches Kommentieren zwischen Tradition und Innovation [in:] Quo vadis, Kommunikation? Kommunikation - Sprache - Medien, ed. I.-N. Creţu, Frankfurt a. M. 2015.

28. Lüger H.-H., Entwicklung der Medienlinguistik [in:] Beiträge zur Fremdsprachenvermittlung 58, 2016.

29. Püschel U., Von der Pyramide zum Cluster. Textsorten und Textsortenmischung in Fernsehnachrichten [in:] Medienkultur - Kulturkonflikt. Massenmedien in der interkulturellen und internationalen Kommunikation, ed. E.W.B. Hess-Lüttich, Opladen 1992.

30. Püschel U., „Puzzle-Texte“ - Bemerkungen zum Textbegriff [in:] Die Zukunft der Textlinguistik. Traditionen, Transformationen, Trends, ed. G. Antos, H. Tietz, Tübingen 1997.

31. Sandig B., Textstilistik des Deutschen, Berlin, New York 2006.

32. Skowronek B., Mediolingwistyka. Wprowadzenie, Kraków 2013. 
33. Storrer A., Hypertextlinguistik [in:] Textlinguistik. 15 Einführungen, ed. N. Janich, Tübingen 2008 .

34. Stöckl H., Medienlinguistik. Zu Status und Methodik eines (noch) emergenten Forschungsfeldes [in:] Pressetextsorten jenseits der, News'. Medienlinguistische Perspektiven aufjournalistische Kreativität, ed. Ch. Grösslinger et al., Frankfurt a. M. et al., 2012.

35. Witosz B., Genologia Lingwistyczna. Zarys problematyki, Wydawnictwo Uniwersytetu Śląskiego, Katowice 2005.

36. Witosz B., Grundlagen der Textsortenlinguistik, translated by A. Hanus, I. Szwed, P. Lang, Frankfurt a. M. 2015.

37. Wojtak M., Gatunki prasowe, Lublin 2004.

38. Wolańska-Köller A., Funktionaler Textaufbau und sprachliche Mittel in Kochrezepten des 19. und frühen 20. Jahrhunderts. Perspektiven Germanistischer Linguistik, Stuttgart 2010.

39. Wolańska-Köller A., Das E-Kochrezept - Gegenwart oder immer noch Zukunft? [in:] Osnabrücker Beiträge zur Sprachtheorie (OBST), Vol. 87, 2015.

\section{INTERNET SOURCES}

1. Fritz G., Dynamische Texttheorie. Gießener Elektronische Bibliothek, Gießen 2013, http://geb.uni-giessen.de/geb/volltexte/2013/9243/ (access: 10.03.2017).

2. Wolańska A., ze współudziałem Dyńkowska M., Lehmann F., Bessere Kochrezepte? Zur Qualität eines Texttyps im Web, Fest-Platte für Gerd Fritz, ed. I. Bons, T. Gloning, D. Kaltwasser, Gießen 2013, http://www.festschrift-gerd-fritz.de/index.php?main=articles\&article_id=57 (access: 20.03.2018).

\section{OD MONOMODALNEGO PRZEPISU KULINARNEGO DO MULTIMODALNEJ OFERTY. UJECIE TEKSTOLOGICZNE I MEDIOLINGWISTYCZNE}

Przepisy kulinarne jeszcze nie tak dawno zaliczane były do 'oczywistych' gatunków tekstu funkcjonujących „,bezproblemowo w sferze życia codziennego”, gdyż ich stosunkowo nieskomplikowana struktura nie przysparzała ani większych trudności z rozpoznaniem i kwalifikacją, ani z opisem genologicznym poszczególnych egzemplarzy tekstowych. Chodzi tu zarówno o reproduktywne, jak i produktywne kompetencje odbiorców i producentów gatunków tekstów. Przepisy kulinarne funkcjonują bowiem bez jakichkolwiek przeszkód, związanych z ich rozpoznawalnością, w oficjalnej i prywatnej komunikacji. Jednakże współczesne multimedialne i multimodalne formy egzystencji przepisów kulinarnych zdają się podważać tezę o ich oczywistości. Czy wobec tego te multimodalne i coraz częściej multifunkcjonalne byty należy uznać za wariant wzorca tekstowego, multimodalnie funkcjonujące pole gatunków tekstu w rozumieniu Adamzik, czy może za hipertekst w powszechnym jego rozumieniu? A może w grę wchodzą jeszcze inne możliwości typologiczne? Artykuł ma na celu przedyskutowanie powyższych wątpliwości z punktu widzenia lingwistyki tekstu i mediolingwistyki oraz rozważenie możliwości typologicznych na przykładzie zaczerpniętym z mediów cyfrowych. Pragmalingwistyczna analiza korpusu badawczego wspomnianej multimodalnej oferty internetowej pozwala na wysunięcie tezy, iż w komunikacji medialnej konfrontowani jesteśmy z coraz nowszymi, coraz bardziej wyszukanymi formami i sposobami przekazu, które przez swoją coraz większą kompleksowość stają się coraz większym wyzwaniem dla 
lingwistów, próbujących je skategoryzować i dookreślić. Dlatego też, zgodnie z postulatami Adamzik, próbujemy przede wszystkim opisać i doświetlić z różnych perspektyw analizowaną przez nas wielkość.

Słowa kluczowe: przepis kulinarny, gatunek tekstu, zmiana/transformacja gatunkowa, hybrydyzacja, oferta multimodalna, formaty medialne, medialna transformacja.

DOI: $10.7862 /$ rz.2018.hss.40

Przestano do redakcji: lipiec $2018 \mathrm{r}$.

Przyjęto do druku: wrzesień 2018 r. 